\title{
Contratos de agência e representação na prática internacional
}

Sumário - Introdução: Importância do tema; Definições; O problema da ordem pública. O aspecto conflitual: Lei aplicável; A legislação brasileira, alcance e extensão; Mecanismos para solução de disputa.

O contrato: Contrato de Agência e legis/ação concorrencial; Definições e elementos básicos do contrato; Obrigações do intermediário; Obrigações do fabricante; cessação do contrato e disposições finais.

\section{Introdução}

\section{Importância do tema}

Na prática do comércio internacional, assim como no interior dos países, uma economia concorrencial obriga as empresas a procurar, sem desfalecimentos, o aumento do volume de suas vendas. Isso é obtido através da busca de novos mercados, e ao estabelecimento de relações de cooperação com outras empresas, empresários e, por vezes, auxiliares do comércio.

Dois são os focos em torno dos quais desenham-se essas atividades: o estímulo às vendas e a organização de centros de distribuição de mercadorias e produtos.

Ao promover o estímulo às vendas, as empresas recorrem não só às técnicas de "marketing" como ao estabelecimento de relações jurídicas, as mais variadas, com pessoas que, estimuladas pela participação em parte dos lucros, possam obter novos fregueses. Os centros de distribuição, por sua vez, servem a exibir os produtos, tornálos facilmente acessiveis aos fregueses, proporcionar assistência técnica, manutenção e fornecimento de complementos e peças. 
1. MERCADAL, Barthelemy \& JANIN, Philippe. Les contrats de cooperation enter entreprises. Paris, Lefebre, 1974. p. $350, \S 1086$.

2. BORTOLOTTI, Fabio. Guida alla stipulazione di contratti con agenti e concessionari all'estero. Milão, II Sole 24 ore, s.d.p.29.

3. FERREIRA, Waldemar. Tratado de direito comercial. São Paulo, Saraiva, 1960, v. 11, p. 145.

4. REQUIĀO, Rubens. Do representante comercial. 2. ed. Rio de Janeiro, Forense, 1977. p. 55-9.

5. REQUIĀO, Rubens. Do representante comercial. 2. ed. Rio de Janeiro, Forense, 1977. p. 59.
Em ambas as atividades há diversos tipos de contratos: o "franchising", a cessão de marcas, as vendas em comum através de "joint ventures" ou de consórcios, outras formas de organização sendo possíveis e numerosas demais para se relacionar. Mas tão-só a representação comercial e a agência é que serão examinadas aqui.

\section{Definições.}

Tem-se agrupado a representação e a agência sob uma denominação ampla, que, embora menos precisa do ponto de vista jurídico 1 é mais adequada à realidade econômica.

Os conceitos de representação e de agência são variados, segundo o país. Um autor italiano2 coloca-os sob a rubrica genérica de "intermediários".

- A palavra representação não é, aliás, adequada, pois serve para designar o "obrigar-se por conta de outrem", no âmbito do direito. Foi, e é usada também na acepção econômica, designando a intermediação entre o produtor e o comprador. Daí, falarem os italianos em "agente con", ou "senza rappresentanza". No Brasil, como se sabe, a Lei consagrou o uso comum, chamando de "representante comercial" à:

"pessoa jurídica ou física, sem relação de emprego, que desempenha, em caráter não eventual por conta de uma ou mais pessoas, a mediação para a realização de negócios mercantis, agenciando propostas ou pedidos, para transmiti-los aos representados, praticando ou não atos relacionados com a execução dos negócios" (Lei n. 4.886, de 9/12/1965, art. 1.).

Outra figura foi regulamentada, com funções próximas: o concessionário. Antes de falarmos das diferenças deste com o representante comercial, é preciso marcar a separação que existe no direito brasileiro - mas que não é aceita universalmente - do mandato comercial e da representação comercial.

O parágrafo primeiro do artigo $1^{\circ}$ da lei supracitada marca a existência de regimes jurídicos diversos para o representantemandatário - o "agente con rappresentanza" dos italianos - e para o representante não mandatário. Não é o caso de retomar a exposição da discussão doutrinária sobre a natureza do mandato, tão bem exposta por Waldemar Ferreira3 e sintetizada por Requião4.

É preciso, ainda, distinguir comissão mercantil de representação comercial, no direito brasileiro, sendo a primeira "mandato sem representação", como quer Requião5. Define-a o artigo 185 C.Com., como:

"o contrato do mandato relativo a negócios mercantis quando, pelo menos, o comissário é comerciante, sem que nesta gestão seja necessário declarar ou mencionar o nome do comitente".

Assim, no caso da representação o produtor aparece, agindo o representante comercial em seu nome; na comissão o comissário, como estabelece o art. 166 C. Com.:

"fica diretamente obrigado às pessoas com quem contratar, sem que estas tenham ação contra o comitente, nem este contra elas". 
6. BORTOLOTTI, Fabio. Guida alla stipulazione de contratti con agenti e concessionari all'estero. Milão, II Sole 24 Ore, s.d.p. 24.
7. REQUIÃO, Rubens. Do representante comercial. 2. ed. Rio de Janeiro, Forense, 1977. p. 09 .

8. REQUIÃO, Rubens. Do representante comercial. 2. ed. Rio de Janeiro, Forense, 1977 p. 10 ess., para breve histórico da agência ou representação comercial no Brasil e no direito comparado.
Chega-se, assim, à última das distinções a fazer-se no seio do direito brasileiro, aquela entre representante comercial e concessionário.

As características que permitem distinguir, do ponto de vista jurídico, o agente do concessionário residem no fato de que:

"o agente limita-se a facilitar a celebração de contratos entre o fornecedor e o freguês (ou no caso do agente com representação - a concluir o contrato em nome e por conta do fornecedorl; o concessionário adquire o produto para revenda" 6 .

Um quadro, elaborado por Bortolotti, permite, sob o ponto de vista econômico ou negocial, distinguir as características de diferentes tipos de intermediários, escalonados de acordo com o grau de independência e as vantagens e desvantagens de cada atividade:

\begin{tabular}{|c|c|c|c|c|}
\hline & $\begin{array}{l}\text { Distribuidor ou } \\
\text { cessionário }\end{array}$ & $\begin{array}{l}\text { Representante ou } \\
\text { agente com man- } \\
\text { dato }\end{array}$ & $\begin{array}{l}\text { Representante ou } \\
\text { agente sem man- } \\
\text { dato }\end{array}$ & $\begin{array}{l}\text { Representante } \\
\text { subordinado (via- } \\
\text { jante) }\end{array}$ \\
\hline Funçø̃es tipicas & $\begin{array}{l}\text { Adquire e revende } \\
\text { emnome próprio }\end{array}$ & $\begin{array}{l}\text { Transmite ordens } \\
\text { do produtor }\end{array}$ & $\begin{array}{l}\text { Conclui contratos } \\
\text { em nome e por } \\
\text { conta do produtor }\end{array}$ & $\begin{array}{l}\text { Atua como agente } \\
\text { (com ou sem man- } \\
\text { dantel mas sob o } \\
\text { controle do fabri- } \\
\text { te }\end{array}$ \\
\hline Remuneração & $\begin{array}{l}\text { Diferença entre } \\
\text { preco de aquisi- } \\
\text { çaoe de revenda }\end{array}$ & \multicolumn{2}{|c|}{ Comissåo sobre negócios efetivados } & $\begin{array}{l}\text { Comissão ou fixo } \\
\text { mensal, ou ambos }\end{array}$ \\
\hline $\begin{array}{l}\text { Onus suplemen- } \\
\text { tares }\end{array}$ & $\begin{array}{l}\text { Nenhum (em cer- } \\
\text { tos paises, indeni- } \\
\text { zaçăo de provisão } \\
\text { e/ou clientela). }\end{array}$ & \multicolumn{2}{|c|}{$\begin{array}{l}\text { Comum a indenizacão de rescisão, ou de } \\
\text { clientela. Excepcionais, Ônus previdên- } \\
\text { ciários }\end{array}$} & $\begin{array}{l}\text { Pesados: indeni- } \\
\text { zação de recisão, } \\
\text { previdência, } \\
\text { legislaçăo traba. } \\
\text { lhista, etc. }\end{array}$ \\
\hline $\begin{array}{l}\text { Onus de organiza- } \\
\text { ção }\end{array}$ & $\begin{array}{l}\text { Pequenos: a re- } \\
\text { venda è obriga- } \\
\text { cão do cessioná. } \\
\text { rio }\end{array}$ & $\begin{array}{l}\text { Médios: o produ- } \\
\text { tor fatura aos cli- } \\
\text { entes }\end{array}$ & $\begin{array}{l}\text { Pequenos: sobre } \\
\text { tudo quando o a. } \\
\text { agente mantém } \\
\text { depósito }\end{array}$ & $\begin{array}{l}\text { Fortes: o produtor } \\
\text { deve controlar a } \\
\text { geståo }\end{array}$ \\
\hline $\begin{array}{l}\text { Controle de politi- } \\
\text { ca de venda da cli- } \\
\text { entela }\end{array}$ & $\begin{array}{l}\text { Fraco: pode-se a- } \\
\text { centuar contratu- } \\
\text { almente, mas o } \\
\text { produtor pode } \\
\text { perderaclientela }\end{array}$ & \multicolumn{2}{|c|}{$\begin{array}{l}\text { Médio: muito dependente do contrato, e } \\
\text { o fabricante conhece a clientela e seus } \\
\text { endereços, pois fatura }\end{array}$} & $\begin{array}{l}\text { Forte: o fabrican- } \\
\text { te pode determi- } \\
\text { nar os detalhes da } \\
\text { ação do viajante }\end{array}$ \\
\hline $\begin{array}{l}\text { Riscos comerci- } \\
\text { ais }\end{array}$ & $\begin{array}{l}\text { A cargo do con- } \\
\text { cessionário }\end{array}$ & \multicolumn{3}{|c|}{ Quase todos a cargo do produtor } \\
\hline
\end{tabular}

Naturalmente, a apresentação é duma clareza que é rara na realidade, em que as nuances tornam difícil distinguir. Os diferentes tipos retro referidos não esgotam as possibilidades de intermediação, pois há entre outros, ainda, o agente ocasional - chamado entre nós de corretor - é o que "pode intervir em todas as convenções, transacões e operações mercantis" (Código Comercial, art. 45), conhecido entre os italianos como "proccaciatore d'affari". Aliás, nosso Código Comercial (art. 35) emprega a expressão "agente" para os auxiliares do comércio em geral, ao contrário das leis européias, que a empregam em relação à representação comercial7.

A expressão agente, no Brasil, é de uso comum na doutrina, tendo sido consagrada pelo Projeto do Código Civil Brasileiro8. Assim, e porque é corrente na maioria dos países, a empregaremos. 
9. REQUIÃO, Rubens. Do representante comercial. 2. ed. Rio de Janeiro, Forense, 1977. p. 15, citando, após, lição de Joseph Hemard.

10. Para um levantamento extenso dos regimes jurídicos da agência, ver os relatórios gerais e nacionais apresentados aos Congressos de Arnhem e de Viena, da UIA, em 1965 e 1966, atualizados e publicados em 1969 pelo editor Bruylant, Bruxelas.

11. LOUSSOUARN, Yvon \& BREDIN, Jean-Denis. Droit du commerce international. $\mathrm{Pa}$ ris, Sirey, 1969. § 128.

12. GRAULICH, Paul. Règles de conflit et règles d'application immediate; melanges Dábin II. Paris, Dalloz, 1961.
Entretanto, é preciso ter presente que circunstâncias locais fizeram com que, em cada país, se fizessem distinções entre os diversos gêneros de agentes, dando-lhes denominações diferentes e submetendo-os a vários regimes jurídicos, entre os quais o do Direito do Trabalho - é o caso, por exemplo da lei francesa de 18/07/37. Esta havia disciplinado as funções dos "vendedores, representantes e pracistas", os VRP, inserindo a relação jurídica no Livro 1 do Código do Trabalho (art. 29, letras " $k$ " a "s"). Mas, como lembra Requião, criou-se a denominação "de'representantes mandatários', para os disntinguir (os autônomos) dos representantes comerciais, denominação ocupada pelo Direito do Trabalho"9. Na Itália, por sua vez, a disciplina do contrato de agência está no "Codice Civile" de 1942 lart. 1742), excluindo-a do direito do trabalho.

\section{O Problema da ordem pública}

Como quer que seja, o "lobby" dos agentes e representantes obteve em toda parte legislação que os protege.

Podemos lembrar, no elenco das normas que disciplinam a atividade, além do "Codice Civile" italiano, arts. 1742 a 1753, a lei suíça de 4 de fevereiro de 1949, que modificou o artigo 418 do Código das Obrigações; a lei francesa ora em vigor (Decreto 68 - 765, de 22 de agosto de 1968); a Seção VII, arts. 84 a 92 do HGB, do Código de Comércio Alemão; o Código de Processo Japonês de 1951, arts. 46 a 55; a Lei n: 14.546, de 27 de outubro de 1958, da Argentina, não nos esquecendo a nossa Lei n:4.886, de 9 de dezembro de 196510.

Essas leis são de, ou contêm, normas a que, no Direito Internacional Privado, se chama de aplicação imediata - as "Lois de police" tão caras a Franceskakis.

O art. 10", alínea " $i "$ ", do Código Napoleão, empregava a expressão "Lois de police et de sureté", tendo a primeira expressão sido adotada para designar normas de aplicação imediata, assim denominadas porque afastam a legislação estrangeira indicada pelas regras de conflito de leis. Trata-se de disposiç̃es imperativas que, no dizer de meu Mestre Loussouarn, "... se multiplient et enserrent la volonté des contractants dans des frontières sans cesse plus étroites", e lembra ainda o professor da Universidade de Paris que, por exemplo, "... dans le contract de travail, la place des prescriptions administratives relatives à I'higiene et à la securité du travail va croissant de telle sorte que'il est inconcevable qu'elles relèvent d'une loi autre que celle du pays surle territoire duquelle travail est effectué" 11 .

A existência e o alcance dessas normas são hoje reconhecidos universalmente, como faz praça o célebre "caso Boll", da CIJ, em que se as julgou aplicáveis em matéria de direito de família e proteção do menor, por extensão podendo-se imaginar aplicáveis em outras matérias.

Graulich 12 escreveu que as regras de aplicação imediata teriam precedência sobre as de conflito de leis, cujo alcance delimitariam. A opinião desse autor não é, porém, incontrastável, e o debate sobre o real alcance e até mesmo a existência das "lois de police" ainda perdura. Fica, porém a menção, e encarar a sua aplicação é prova de rea- 
13. LOUSSOUARN, Yvon \& BREDIN, Jean-Denis. Droit du commerce international. $\mathrm{Pa}$ ris, Sirey, 1969. § 128.
14. TENORIO, Oscar. Direito internacional privado. 11. ed. Rio de Janeiro, Freitas Bastos, 1976. §870.

15. VALLADÃO, Haroldo. Direito internacional privado. Rio de Janeiro, Freitas Bastos, 1970. v.2.

16. SERPA, Lopes, Miguel Maria de. Comentário teórico e prático da LICC. Rio de Janeiro, Freitas Bastos, 1959. V.2. $\$ 240$.

17. BAPTISTA, Luiz Olavo. Contratos internacionais. Revista Forense, Rio de Janeiro, 270 (2): 87-90, abr. / jun., 1980. lismo, eis que a maırıa dos tribunais tende a empregá-las, quando mais não seja porque obedece escrupulosamente à lei... do mínimo esforço. Outra realidade a encarar é o alcance territorial dessas normas13.

Colocadas estas premissas, podemos passar a examinar os contratos internacionais de agência e representanção, sob o prisma conflitual (1) e da sua elaboração e redação (2).

\section{Oaspecto conflitual}

Em todo o contrato internacional conteúdo e forma devem ser examinados, ao se redigi-lo ou prepará-lo, á sombra das regras conflituais, para a determinação de qual seria a lei aplicável. Em nosso caso, uma lei merece consideração especial - a brasileira. Assim é que começaremos por examinar as hipóteses de lei aplicável a qualquer contrato de agência ou representação (a) , para encarar o alcance e a extensão da Legislação Brasileira face a esse contrato (b), concluindo com os mecanismos para solução de disputas (c).

\section{a. Leiaplicável}

A importância de se determinar a lei aplicável aos contratos de agência e representação decorre principalmente de que: a) quando tal lei contiver disposições imperativas, estas podem ser de molde a revogar ou negar vigência ao contrato, ou na melhor das hipóteses a alguma de suas cláusulas; b) a lei aplicável é que supre as lacunas do contrato e tudo o que seja relativo à aplicação e interpretação do mesmo ou aquilo que esteja subjacente à convenção.

Podemos desde logo imaginar, em relação a um contrato já celebrado, as hipóteses de ter sido escolhida ou não a lei aplicável.

\section{$\S 1^{\circ}$ - - A falta de escolha expressa da lei aplicável}

Não havendo escolha da lei aplicável pelas partes, se o contrato tiver sido proposto por pessoa residente no Brasil, ou destinar-se à execução no Brasil, é o artigo 9. da LICC que determina a lei aplicável.

Como corolário, pode-se admitir que, para que se escolha outra lei, é preciso que o contrato se constitua fora do Brasil, pois, como lembra Oscar Tenório:

"o artigo 9: (da LICC) não exclui a aplicação da autonomia da vontade se ela for admitida pela Lei do país onde se constituir a obrigação"14.

Entretanto, a regra da autonomia no direito brasileiro, tal como a consagrava o artigo 13 da antiga Introdução ao Código Civil, foi defendida por juristas do peso de um Haroldo Valladão15 e de um Serpa Lopes16.

O certo é que, se o nosso direito pode admitir a autonomia da vontade, o juiz brasileiro não procede a uma investigação da vontade implícita ou tácita das partes. Utiliza-se, no silêncio do contrato, dos critérios da LICC, nossos conhecidos 17.

Para os contratos celebrados entre ausentes, por via de cartas, 
18. RECURSO 69.377 - Revista Trimestral de Jurisprudência. Brasilia, 60. 446, maio 1972.

19. TENORIO, Oscar. Direito internacional privado. 11. ed. Rio de Janeiro, Freitas Bastos, 1976. $§ 876$.

20. CASTRO, Amilcar de. Curso de direito internacional privado. Rio de Janeiro, Forense, s.d., p. 176, § 206.

21. SERPA LOPES, Miguel Maria de. Comentário teóricoprático da LICC. Rio de Janeiro, Forense, 1959. p. 176, § 292.

22. BATIFFOL, Henri. Les conflits de lois em matière de contrats; étude de droit international privé. Paris, Librairie du Recuel, Sirey, 1938. p. 398 9. telegramas, telex, ou mesmo telefone, a regra, no Brasil, é a do art. $9^{\circ}$, § 2 . , da LICC, que manda adotar a lei do lugar da residência le não domicílio) do proponente18.

Trata-se de solução que apresenta algumas dificuldades. A prática, hoje, dos contratos entre ausentes é o uso do telex - que propicia diálogo entre os futuros contratantes. Podem haver - e é freqüente - várias contrapropostas à proposta inicial, mas é esta que deve ser levada em conta:

"O exame da proposta e da contra-proposta é extremamente difícil quando ocorre aceitação parcial da contra-proposta e também parcial pelo contra-proponente, da proposta. O lugar da residência da pessoa donde partiu a proposta inicial determina o direito a aplicar ao contrato 19 .

Sem nos alongarmos mais sobre a matéria, convém lembrar que Amilcar de Castro20 chamava a atenção para a expressão residência, porque, a seu ver, "lugar onde residir o proponente"é "lugar onde estiver o proponente", acentuando a característica da transitoriedade da residência, oposto à estabilidade do domicílio; Serpa Lopes 21 concorreu com a noção de que a residência deve conformarse com a "sua própria função de elemento localizador do contrato".

Outro aspecto a lembrar-se - também usual na prática internacional - é o do contrato celebrado por mandatário que faz a proposta, é claro, em nome do mandante. A residência será a deste, pelo sistema brasileiro.

Já na Alemanha, nos EUA e na França, utilizou-se a residência ou domícilio do mandatário, como lembrava meu professor Batiffol em sua tese22. Por sua vez a lei italiana, art. 25 das disposições gerais sobre as leis, que precedem o "Codice Civile", estabelece que: "Le obbligazioni che nascono dal contratto sono regolate della legge nazionale deicontraenti se é commune: altrimenti da quella del luogo nel quale il contratto é statto concluso. É salva in ogni caso la diversa volantà delle parti".

Pode ocorrer que o juiz não seja o brasileiro; e a probabilidade de que a regra da autonomia predomine é então suficientemente grande para nos permitir alguma especulação sobre o assunto.

Batiffol explica a ação do juiz no silêncio das partes quanto à lei aplicável com a teoria da "localização objetiva". Segundo o mestre, o juiz não busca a lei aplicável "dans une pretendue volonté tacite on implicite des contractants, recherche qui serait d'ailleurs le plus souvent divinatoire. II procéde en realité à une localisation objective du contrat" 23 , a teoria é levada à sua conseqüência lógica final, pela afirmação de que mesmo na hipótese em que as partes manifestarem expressamente a sua vontade quanto à lei aplicável, nada mais fizeram que localizar o contrato. Não iríamos tão longe. Mas o fato é que o juiz deve localizar o contrato e buscar para isso elementos que tenham influência sobre o mesmo.

O fato do representante ter mandato pode levar o juiz a inclinarse para indicar a lei aplicável a este. Se o representante não é autôno- 
24. LOUSSOUARN, Yvon \& BREDIN, Jean-Denis. Droit du commerce internacional. $\mathrm{Pa}$ ris, Sirey, 1969. p. 646.

25. LOUSSOUARN, Yvon \& BREDIN, Jean-Denis. Droit du commerce international. $\mathrm{Pa}$ ris, Sirey, 1969. p. 649 /decisão da Ch. Com. de 09 de novembro de 1959).

26. SIMON, M. Depitre; Chambre Sociale 1er juillet de 1964. Revue Criminel de Droit International Privé. 48, 1966. mo, é a lei aplicável ao contrato de trabalho (sempre segundo as normas conflituais do país do juiz).

Das diversas hipóteses aplicáveis, a "lex loci executionis" é a que parece melhor aplicar-se ao contrato de agência. Entretanto, a lei da autonomia ligada à "lex loci executionis" teria a vantagem de aplicar-se quer ao representante autônomo, quer ao subordinado. Nesse caso, uma só regra resolveria o conflito sem que fosse preciso, antes, passar pela qualificação do contrato. Mas, como já se disse:

"Malheureusement, une telle vision des choses procède d'un excessif optimisme pour deux raisons. Si la competence supplétive de la "lex loci executionis" semble admise sans contestation en matière de contrat de mandat, elle demeure incertaine dans le contrat de travail ou le principe même de la compétence de la loi d'autonomie à suscitité des réticences, et est ecarté par certains au profit d'un rettachement imperatif" 24.

Outra hipótese é a aplicação da lei da sede da empresa produtora, solução que foi encontrada pela Corte de Cassação francesa, para resolver litígio entre produtor francês e representante que, pessoa física, agia em vários países da América Latina 25.

Pode-se, ainda, encontrar a solução italiana da nacionalidade comum das partes, mesmo fora da Itália, como se vê de uma decisão da Cassação francesa26.

Finalmente, as dúvidas sobre a lei aplicável poderão vir a dissipar-se, se vier a ser posto em vigor o projeto de convenção, de 1977, da Conferência de Haya sobre o Direito Internacional Privado (da qual o Brasil, em má hora, retirou-se), "sobre os contratos de intermediação e representação". Esse projeto prevê a aplicação da lei escolhida pelas partes ou, na sua falta, a do país onde o agente está estabelecido.

\section{$\S 2^{\circ}$ - A escolha de uma lei pelas partes}

Admitida a possibilidade de escolha, pelas partes, de lei para reger o contrato, várias hipóteses são prováveis. Dentre elas, a lei do local da execução, ou a do país do domícilio do intermediário, que em geral coincidem, a lei do país do produtor ou a lei de um terceiro país são as mais importantes.

A lei do país do produtor, muitas vezes, é afastada como improvável ou inconveniente porque, se houver disposições imperativas no país do intermediário, estas se aplicarão. Entretanto, poder-se-ia argumentar que estando numa posição eventualmente mais forte poderia o representado optar por sua própria lei, que conhece melhor. Nesse caso, se fosse demandado no foro de seu domicílio, ou se este fosse competente para conhecer de questão contra o intermediário, aí teria possibilidades de fazer predominar a sua própria lei.

A lei do país de domicílio do intermediário, como se apontou atrás, é provavelmente a que teria melhor possibilidade de aplicação, em razão de ser o lugar mais provável da execução principal do contrato. Em geral, as diferentes legislações variam no grau de proteção que oferecem aos intermediários, quer submetendo os contratos à le- 
27. LOUSSOUARN, Yvon \& BOUREL, Pierre. Droit international privé. Paris, Dalloz, 1978. p. 176.

28. BAPTISTA, Luiz Olavo. Contratos internacionais. Revista Forense, Rio de Janeiro, 270(2): 87-90, abr./jun., 1980. gislação trabalhista, quer a outra norma especial. Aliás, a maior adequação das leis de país em que o contrato será executado conduziu alguns tribunais, como os franceses, a escolhê-la na falta de estipulação pelas partes27.

A lei de um terceiro país, embora seja a hipótese que maior liberdade pode oferecer às partes, é a que maiores riscos oferece, pois há que estabelecer um nexo entre essa norma e o contrato 28.

\section{b. A legislação brasileira, alcance e extensão}

Já vimos que nossas leis conflituais contemplam duas hipóteses: a do lugar da proposta e a do lugar na celebração do contrato la qual pode levar, por via indireta, à escolha da lei que as partes quiserem).

A aplicação da lei brasileira pode decorrer, pois, ou da residência do proponente, ou de escolha expressa pelas partes (na hipótese de celebração no exterior, ou de ser o Brasil o lugar da execução do contratol.

A solução da escolha da lei brasileira, quer para o agente representante, quer para o usuário de seus serviços, brasileiros, é útil por permitir-Ihes aplicar um direito moderno e conhecido - o que oferece vantagens quer na redação do contrato, quer na execução do mesmo. Mas a disposição será de pouco utilidade, se o foro escolhido (na medida em que isso seja possível) for outro que não o brasileiro.

No caso de empresa brasileira que empregue intermediário no exterior, a escolha da nossa lei deve ser antes objeto de algumas ponderações. Em primeiro lugar, é preciso saber se no país do intermediário há (é o caso da Argentina, por exemplo), ou não, normas imperativas que o protejam ("verbi gratia", a Inglaterra). Em havendo normas imperativas no país do intermediário, é preciso verificar se essas são de ordem pública internacional - e podem ser derrogadas pela escoIha de uma lei estrangeira - ou não.

Nesta última hipótese, ainda, a lei brasileira poderia ser aplicável, se o foro fosse o do Brasil e se não houvesse choque entre a lei daquie a do país do intermediário. A adoção de cláusula dispondo que a nulidade de alguma das disposições do contrato não acarrete a das demaisé, aí, muito útil.

A escolha (por via direta ou indireta) da lei brasileira faz com que a nossa legislação - a da representação comercial e dos Códigos Civil e Comercial - seja aplićavel. A solução não é perfeita, pois, como é óbvio, trata-se de normas dispostas para uso interno e não internacional.

Como se vê, do ponto de vista de conflito de leis, o problema é de difícil solução. Daí, surgirem os mecanismos contratuais de solução de disputas.

\section{c. Mecanismos para solução de disputas}

As partes, em um contrato, que não tenham conseguido se compor amigavelmente, têm que recorrer a terceiros para resolver 
suas divergências. Ou é o Judiciário, com os ônus e riscos das demandas, ou é a via da arbitragem. Assim, há que encarar a escolha de foro ou jurisdição competente $(\S 1 \%$ ), antes de examinar o interesse da arbitragem para resolver questões entre fabricantes e seus agentes ( $\S$ 2.).

\section{§1․ - Cláusulas de escolha de foro ou jurisdição}

Já acenamos mais atrás para a possibilidade de se escolher o foro do produtor. Escolhido este, duas possibilidades se oferecem quanto à lei a ser aplicada (escolhida ou indicada pela norma conflitual local): a lei do juiz ou uma lei estrangeira.

A primeira apresenta vantagens, especialmente quanto à maior segurança do juiz e das partes, quanto à interpretação possivel; no caso de escolha expressa dessa lei, acarreta a certeza de sua aplicação.

Quando a execução do contrato se der em país onde se admita a competência concorrente do foro contratual, ou a exclusão do foro indicado pela lei, em favor deste, a escolha do foro do produtor é mais conveniente. Isso porque eventuais disposições de ordem pública poderão ser afastadas na decisão da questão. Mas, se houver "exequatur", podem elas voltar a intervir, afastando a homologação da sentença estrangeira no que ela colidir com o direito local.

Um importante tratado internacional, a Convenção de Bruxelas de 27/09/68 sobre o reconhecimento e execução de sentenças, em vigor desde 01/02/73 no seio da CEE e que contou com a adesão de outros países europeus, em 05/10/78, prevê expressamente no seu art. 17 a eleição de foro, que determina a competência jurisdicional, com afastamento da do juiz indicado pelo direito interno desses países.

Fora esses membros da CEE, é difícil definir uma regra geral, pois não há senão poucos tratados bilaterais sobre o assunto, e, que se saiba, o Brasil não é parte em nenhum deles.

A jurisdição competente, por via da escolha das partes, pode ser a do país do produtor. O maior inconveniente prático dessa situação é que o juiz aplicará um direito que não conhece, e que a prova desse direito incumbe às partes ou pelo menos a uma delas.

Uma outra hipótese é a da escolha pelas partes do tribunal de um país que não seja o do produtor, ou o do intermediário, escolha que, segundo já dissemos, é arriscada porque pode ser facilmente acusada de fraudulenta, se algum desses países tiver disposições imperativas em suas leis.

Pode-se, ainda, adotar a regra de que o tribunal competente será o do domicílio do réu, solução que, se é prática do ponto de vista negocial e evita eventuais conflitos de jurisdição, é pobre e amarra as partes à lei indicada pela regra de conflito local. Além disso, coloca graves dificuldades quanto à conciliação das duas leis aplicáveis em hipótese ao contrato, ou a conciliação do texto deste às exigências de ordem pública dos dois países. 
Uma breve vista de olhos sobre o direito comparado é importante a este passo, para ilustrar quão delicado é o problema da escolha do foro.

A competência "ratione materiae" pode ser, seja dos tribunais comuns ou comerciais, seja a de um equivalente da nossa justiça do trabalho, por exemplo, os "conseils de prud'hommens" da França. Esta última justiça, no caso do representante subordinado, é competente na França, Austria, Bélgica, Alemanha, Portugal e Argentina. Em outros países, são os juízes do foro cível e comercial que terão competência, tal como ocorre para os agentes autônomos, inclusive nos países que mantêm justiça do trabalho. Aqui, porém, é preciso lembrar que em bom número de países a jurisdição civil ou ordinária é diferente da comercial. gem.

Essas dificuldades todas levam as partes a ter recurso à arbitra-

\section{§2. - Cláusula arbitral}

São clássicas as observações sobre a conveniência e utilidade da arbitragem nos contratos internacionais: segredo, rapidez, ausência de formalismo, especialização e conhecimentos teóricos dos árbitros, possibilidade de obter julgamento neutro, afastamento das normas de ordem pública interna, menor custo, enfim, há de tudo para todos. Pode-se, porém, perguntar se a arbitragem é cabível em pequenos contratos, e se a neutralidade de certos organismos e árbitros é tão certa, assim como se a matéria é arbitral.

A convenção de New York, de 10/06/1968, resolveu grande parte dos problemas, quando pelo menos o país de uma das partes é signatário do tratado. O Brasil não é signatário, e para nós as disposiç̃̃es dessa convenção não operam. Mas há um problema, que é o fato de que alguns países, como a França e a Bélgica, excluem a possibilidade de submissão à arbitragem de certos contratos.

Quando se trata de agente subordinado, ou assalariado, a arbitragem é admitida expressamente na Austria, na Grã-Bretanha, no Irã (antes da revolução dos Ayatollahs) e na Holanda. É, por outro lado, proibida, nesse caso, na França, Bélgica e Itália. Em Portugual, era (até 1969) admitida diante das "comissões cooperativas", segundo dispunham os artigos 14 e 17 do Código de Processo do Trabalho, então em vigor.

Já no caso do agente autônomo e do concessionário, a arbitragem tem sido admitida e empregada na maioria dos países.

O recurso a organizações especializadas é possivel e útil desde que elas possam assegurar imparcialidade e seriedade.

Com estas observações, podemos já avançar na parte mais específica e prática deste trabalho, que é o conteúdo de um contrato de agência. 


\section{O Contrato}

Não seria possível, nos limites que nos impusemos, o exame de todos os aspectos do contrato.

Encaremos em primeiro lugar os aspectos de direito da concorrência (a), a seguir examinaremos o introito do contrato, que usualmente contém definições e dados básicos (b), e as obrigações do intermediário (c), as do fabricante (d), bem como a cessação do contrato (e).

Ao celebrar o contrato, a primeira preocupação deve ser quanto à forma. Raramente se exige a forma escrita para o agente subordinado ou assalariado, sendo que na França, na Itália, na Suiça e no Brasil, para os contratos de duração determinada é preciso que haja escrito. Havendo cláusulas especiais ou particulares, que fujam do uso local, a forma escrita impõe-se, também, na maioria dos países. Essas exigências são feitas tendo em vista a prova do convencionado.

Já no tocante ao representante autônomo, não encontramos referência à forma especial (ainda que algumas legislações, como a brasileira, contenham disposições que implicam automaticamente na extinção de contrato escrito).

Outras exigências não se apresentam, quanto à forma. De qualquer modo, como em todos os contratos internacionais, convém adotar a forma escrita, quando mais não seja para facilidade de prova. Isto posto, podemos pensar na redação do contrato de representação.

\section{a. Contrato de agência elegislação concorrencial}

Os EUA e a CEE desenvolveram legislação sobre direito da concorrência - ou antimonopolístico - aplicada com seriedade e rigor. Por isso, é preciso examinar essa legislação, que pode e deve ser levada em conta, na elaboração de contratos de agência que possam vir a produzir efeitos nesses paises.

O art. 85, § $1^{\circ}$, do Tratado de Roma, proíbe os acordos ou decisões de associação de empresas, ou práticas, acordadas com o objetivo de restringir a concorrência no interior do mercado comum e suscetíveis de afetar o comércio dos Países-Membros. Ė disposição semeIhante à da legislação "antitrust" dos EUA, os "Sherman Act" e 'Clayton Act".

Podemos, inicialmente, supor que os contratos de agência com cláusula de exclusividade nem sempre se enquadram nessas proibições. No interior de um país, por exemplo, tais cláusulas - como a de exclusividade recíproca, a obrigação de não comprar de outro produtor, ou de contactar clientes fora da zona de concessão - foram consi-

29. TRATADO de Roma, art. 85. $\S 3^{\circ}$. deradas lícitas, em princípio, pela Comissão das Comunidades Européias 29 .

Entretanto, para que cláusulas de exclusividade possam ser incluídas em contrato de representação comercial, é preciso que o agente não seja comerciante, independente do representado. A Comissão das Comunidades Européias caracterizou o comerciante como aquele: a) que mantém, às suas expensas, um estoque considerável dos produtos que representa; b) organiza, também por sua conta, assistência à 
30. DECISÃO de $23 / 11 / 72$. Journal Cfficiel de la Communauté Européen. 272, 05/12/72, 35 .

31. DECISÃO de 02/01/73 Journal Officiel de la Communauté Européen. 140, 26/03/73. p. 17.

32. DECISÃO Bendix/Mertens e Straet, de 01/06/64. Journal Officiel de la Communauté Europeén. 82, 10/06/64, p. 1426.

33. DECISÃO VOLK/ Vervaeck, de 09/07/69. Recueil - 1969, p. 295. DECISÃO CADILLON/ Höss, de 06/05/75. Recueil. 1971, p. 351 clientela; c) tem autonomia para determinar os preços ou condições das representações. Esses são os princípios gerais, que, na prática, foram aplicados com interpretação elástica.

O caso "Pittsburg Corning Europe" 30 teve como conseqüência firmar o precedente de que um intermediário remunerado à base de comissões, por período determinado, que ao fim desse período passa a comprador-revendedor (ou concessionário), pode ser considerado comerciante independente, e as cláusulas de exclusividade do contrato anuladas com base no artigo 85 do Tratado de Roma.

Outros exemplos são os de representantes que contrataram com "Indústrie Européenne du Sucre" 31 e tiveram os contratos anulados. A Comissão, nesse caso, entre outras considerações, decidiu que as pessoas que agem ao mesmo tempo como revendedoras e representantes dosmesmos produtos não são simples auxiliares do comércio.

Esses exemplos, ainda que baseados em legislação de efeitos regionais, servem para ilustrar o problema da interferência das leis antimonopolísticas na celebração de contratos de agência.

Ponderar-se-á que bastaria não ocorrer a exclusividade para queo contrato escape a essas restrições. Entretanto, isso não ocorre. Contratos de concessão, a atividade de revendedores e atacadistas podem ser e já foram objeto de impugnação pela Comissão32.

São excluídos, porém, da incidência das proibições do Tratado de Roma os contratos passados por fabricantes sediados na Comunidade com agentes situados em outros países. $\mathrm{O}$ art. 85 visa, expressamente, a proteger o comércio entre os Países-Membros. Ao revés, os contratos de fabricantes de países alheios ao Mercado Comum, com agentes situados neste, caem sob o império das restrições do art. 85 , citado33.

Com estas breves observações podemos, agora, passar à estrutura do contrato, a partir de seu preâmbulo.

\section{b. Definições e elementos básicos do contrato}

Tradicionalmente, os contratos iniciam-se com a qualificação e designação das partes e do seu objeto. O contrato de agência também deve iniciar-se dessa forma.

\section{§1. - Identificação das partes}

Ao iniciar a redação do contrato, é preciso indicar claramente, qualificando-as, as pessoas do produtor e do intermediário.

Tratando-se de pessoa física, como éóbvio, indica-se o prenome, o nome, o domicílio, sendo dispensáveis, para o caso de contratos a terem execução no exterior, as exigências, hoje tradicionais nos contratos de nosso direito interno, do número do documento de identididade e de cadastro fiscal. No caso de mandatário, mencionar no corpo do contrato o mandato, que convém registrar no Cartório de Títulos e Documentos, se tiver sido lavrado no exterior, e o número do passaporte, se o procurador for estrangeiro de passagem pelo país.

Tratando-se de pessoa jurídica, verificar se a pessoa que apõe a 
sua assinatura no contrato tem poderes para obrigar a sociedade, quer em razão da função que exerça, quer em razão de procuração que lhe tenha sido outorgada por diretores devidamente habilitados.

Naturalmente, do ponto de vista de direito internacional privado, esta verificação se faz à luz das leis do país no qual a sociedade tem a sua sede, e dos estatutos da mesma. Os mesmos cuidados acima referidos devem ser tomados em relação à procuração.

O fato de que o intermediário seja uma sociedade oferece algumas vantagens, que é bom comentar desde já. Em primeiro lugar, o fato de que, nos países em que há risco de assimilação do agente pessoa física ao trabalhador assalariado, uma sociedade evita isso. Dentre os países em que esse risco pode ocorrer, encontramos a Argentina, a França, a Bélgica e até mesmo, em certa medida, o Brasil.

Em segundo lugar, sob o aspecto da estabilidade temporal, o contrato passado com uma sociedade tem garantia de permanência maior do que aquele passado com o indivíduo. A sociedade tem sua vida e continuidade asseguradas por limites maiores do que os da vida de um indivíduo, sujeita sempre ao imponderável.

Entretanto, é bem de ver que muitas vezes a escolha de uma sociedade se faz, não tanto em razão dela própria, mas "intuitu personae", de determinadas pessoas que a integram, de sua capacidade como vendedores, ou dos seus conhecimentos. Nessa hipótese, será bom, desde logo, prever a inclusão no contrato de cláusula pela qual este será rescindido automaticamente, no caso de transformação, cisão, fusão ou qualquer outra alteração que represente a saída real e efetiva daquele, ou daqueles sócios, em razão da presença dos quais se celebrou o contrato.

\section{§ 2. - O preâmbulo e as definições}

O preâmbulo é, também, usual na prática internacional. Nele é indicada, além dos nomes das partes e do tipo de contrato, a definição de algumas noções, que se destina a evitar repetições inúteis, no teor do contrato.

Assim, identifica-se "fabricante", "representante", "sociedade", "produtos", "território", "agente", "intermediário ocasional"," concessionário" e outras palavras repetidas.

Finalmente, o preâmbulo mencionará, de modo expresso, que todas as palavras ali definidas, quando utilizadas no seio do contrato, serão empregadas com o sentido que lhes foi dado nas definições.

Convém ter presente, ainda, que na redação do contrato, embora alguma noção já tenha sido definida, isso não exclui a possibilidade de vir a ser melhor explicitada, definida, ou detalhada em qualquer das cláusulas seguintes.

Definição do intermediário. É importante definir o intermediário para que ele não se possa assimilar a um tipo que não o desejado expressamente pelas partes, ao celebrar um contrato de determinadas cláusulas, que levem a supor a ocorrência de um contrato de representação comercial, as quais convém afastar desde logo. 
Na definição também se determ!nará se o agente tem, ou não, representação, isto é, se promoverá contratos, que serão concluídos finalmente pelo fabricante, ou se os pode, em nome e por conta do fabricante, concluir.

Também é preciso definir com cuidado quando ocorrem as situações mistas: às vezes o concessionário se vê atribuída a faculdade de promover negócios por conta do produtor e, simultaneamente, obrigado a manter um estoque de produtos do fabricante, que revenderá em seu próprio nome e conta.

Essas situações mistas, mais comuns na concessão que na representação comercial, devem ser cuidadosamente desenhadas no contrato, fazendo-se ressaltar a predominância daquele tipo dentro do qual se deseja enquadrar o intermediário.

Definição dos produtos. Em geral, os fabricantes tendem a colocar no contrato a indicação de que o representante assegurará a distribuição dos seus produtos, sem qualquer outra precisão.

Entretanto, ocorre do fabricante criar novas linhas de produtos baseadas em técnicas mais modernas. O concessionário não está equipado, nem preparado para vender essa mercadoria. Tendo-lhe sido assegurada, entretanto, a representação desses produtos, poderá agir contra o fabricante para lhe exigir a representação desta nova linha de produtos.

Destarte, é extremamente importante colocar, seja nas definições, seja como anexo, a relação dos produtos confiados à ação do agente ou do concessionário.

Nada impedirá que, surgindo novos produtos, convindo às partes incluir a representação deles no contrato, seja este aditado através de carta ou de outro instrumento.

Também quando o fabricante vende seus produtos sob diversas marcas, ou sem marca, a compradores (que neles colocam as suas próprias), é importante definir a situação no contrato, para que fique claro o que o representante deve promover.

Definição do território. No momento de se iniciar uma negociacão, com agente situado em determinado país europeu, por vezes movidos pela ilusão de que na Europa as distâncias são pequenas, muitos fabricantes dão extensão indevida ao território. Acabam criando, assim, para si, uma situação de constrangimento, pois o representante situado na Bélgica não tem acesso ao mercado italiano, e vice-versa.

O território deve, assim, ser definido nas negociações e, após, no contrato, em termos da possibilidade reale não imaginária, desejável, do que pode ser abrangido pela atividade do representante.

Uma solução conciliatória é assegurar a exclusivdade em território menor e determinado, e, a título precário, não sujeito a indenização, em caso de restrição posterior, permitir vendas fora desse territó- 
Quando há mais de um representante dentro de determinado país, é preciso estabelecer referências a subdivisões territoriais, de caráter administrativo, como, por exemplo, uma província, uma comuna, uma cidade, uma região, que estejam definidas em qualquer espécie de texto legal, que permita facilmente identificá-la e datá-la no tempo.

Com essas observações, encerram-se as definições e elementos básicos do preâmbulo do contrato.

É tempo de passarmos às obrigações do intermediário.

c. Direitos e obrigações do intermediário.

O estabelecimento dos direitos e obrigações do intermediário varia de acordo com o grau de detalhamento das negociações e do contrato. Devem-se levar em conta para determiná-los o tipo de produto a ser representado, de um lado, e o gênero de política comercial e os procedimentos administrativos do produtor, de outro. Entretanto, há certos aspectos básicos a serem contidos em todos os contratos de agência: a obrigação do intermediário de promover vendas, o grau de independência do mesmo, a fixação de mínimos de produção, as relações do agente com o público, a existência ou não de estoques em poder do representante, as condições de venda. Ė o que ora veremos.

\section{$\S 1^{\circ}$ - Promoção de vendas}

A primeira das obrigações do intermediário é a de promover as vendas do fabricante. Algumas legislações, como a nossa, ou a italiana (artigo 1.748 do Código Civil), estabelecem-na. A maior parte das leis de diversos países é muda ou imprecisa sobre esta questão. A regulamentação francesa dos V.R.P., por exemplo, não estabeleceu expressamente nenhuma obrigação de promoção de vendas. Ė preciso, então, que se estabeleça a promoção de vendas como obrigação contratual do agente ou do concessionário.

\section{$\S 2$. - Fixação de uma quantidade mínima de produtos a serem vendidos ou estocados}

Muitas vezes se estabelece, como meio de avaliação de produção de certo agente, a obrigação de vender um mínimo de mercadorias anual ou mensalmente. Essa obrigação atribuída ao concessionário, ou ao agente, implica, como é razoável, numa contrapartida de obrigações do fabricante.

Por vezes, o contrato não prevê sanção imediata pelo não cumprimento da quota mínima. Doutras vezes, costuma estabelecer, especialmente no caso de produtos altamente especializados, técnicos ou de díficil mercado, a obrigação de vender tanto quanto a média dos demais representantes ou concessionários. É preciso estabelecer os critérios e a periodicidade dos cálculos, assim como as conseqüências do descumprimento dessa obrigação: rescisão, multa, redução do território, mudanças na exclusividade ou na comissão.

§ 3. - Independência do intermediário

A definição exata do grau de independência dada ao agente ou 
concessionário é importante, para evitar que o mesmo passe da condição de autônomo para a de empregado. A pedra de toque dessa definição está na existência ou não de hierarquia no relacionamento entre representado ou representante. A liberdade que terá o representante de decidir qual a organização que julgue adequada para sua atividade também tem a sua importância.

No contrato de concessão, a latitude das obrigações a serem impostas ao concessionário é maior que na representação comercial. Aqui, um controle estreito, que preveja horários, itinerários, periodicidade de relatórios, adoção de formulários, eleva o risco de desnaturação do contrato, transformando-o em contrato de trabalho.

Em certos países, como a Bélgica e a França, ou a Argentina, esse risco é elevado, ocorrendo uma presunção, afastável quando o agente é pessoa física.

Um estudo detalhado da jurisprudência do país em que o agente atuará, a discussão com um advogado local que tenha experiência na matéria recomendam-se fortemente para a redação dessa cláusula.

No tocante aos contratos de concessão, um dos problemas atinentes à independência do concessionário é a exclusão da responsabilidade do fabricante. Via de regra, o concessionário, enquanto comprador-revendedor, é diretamente responsável em relação aos seus fregueses. Em certos países, a legislação prevê uma responsabilidade direta do fabricante face ao usuário final, à regulamentação relativa às características do produto, etiquetas, e responsabilidade do fato do produto.

\section{§4. - Relações com o público e a publicidade}

Esta é outra das obrigações habituais nos contratos de intermediações. Deve ser definida quanto à sua natureza, extensão e modalidades, para que o contrato seja preciso. Ė conveniente que a ação publicitária seja estabelecida de comum acordo entre fabricante e intermediário. O último porque conhece as características do mercado e o primeiro porque tem uma imagem sua e do produto a defender.

A possibilidade de aparecer em feiras e exposições também deve ser prevista nos contratos internacionais de intermediação. As reflexões feitas a propósito da publicidade aplicam-se aqui também, com o acréscimo de que é preciso prever a responsabilidade pelos custos dessa atuação, que, por vezes, são elevados

\section{$\S 5^{\circ}$ - Condições de venda, estabelecimento de preços}

Trata-se de problema a ser tratado de modo diverso, segundo se trate de agente ou de concessionário.

Os concessionários, em geral, deverão ser submetidos às condições gerais de venda do fabricante, nas quais este deve defender-se, especialmente no tocante à responsabilidade pela qualidade e conformidade do produto. É preciso também definir no contrato os preços de venda do fabricante ao concessionário, os descontos por quantidades elevadas, a possibilidade de repassar estes descontos, estabelecimento das condições de pagamento - prazo e forma. Aspecto 
importante, também, e tendo em vista a existência de diferentes atitudes do legislador, é o estabelecimento do preço mínimo, ou determinado, para revenda. Trata-se de disposição que muitas vezes é inquinada de ilegalidade.

Já no que concerne à agência, o agente sem representação não merece maiores preocupações, pois limita-se a recolher os pedidos, cabendo ao produtor fixar o contrato. Quanto ao agente, com poderes de representação, é oportuno estabelecer nos contratos as obrigações que terá quanto a condições de venda.

$\S 6^{\circ}$ - Outras disposições: território, relatórios, depósito etc.

É preciso também prever no contrato, entre as obrigações do intermediário, o respeito ao seu território ou zona, contemplando a hipótese de vendas fora do território e o regime de sua remuneração, nesse caso, existir ou não, repartir ou não.

Por vezes, como nos EUA, em razão da "cláusula de livre comércio" da Constituição, ou nas Comunidades Européias, em razão do princípio da livre circulação de mercadorias, as proibições de venda fora do território contratual devem ser estudadas com circunspeção.

As obrigações do representante incluem, ainda, as de informar o produtor e defender seus interesses, respeitar e utilizar a marca do fabricante, guardar segredo de informações que tenha recebido, e não praticar atos de concorrência desleal.

Há quem inclua obrigações como a de abertura de depósito para uso do produtor, a aquisição e manutenção de um estoque de mercadorias consignadas ou compradas, bem como de mostruários.

Não nos esqueçamos, por fim, das cláusulas relativas à assistência e garantias à clientela, e teremos resumido as obrigações do intermediário.

É tempo de ver as do fabricante.

d. Obrigações do fabricante

$\S 1$. - Exclusividade

Tal como para o intermediário, é preciso definir a exclusividade, considerando a finalidade com que se a criou, e a possibilidade de não se a conceder.

A seguir, concedida a exclusividade, é preciso examinar o seu alcance, pois, na prática, deve ser tratada de maneira a assegurar ao produtor liberdade de ação compatível com as exigências do intermediário. Escalona-se, desde a exclusividade completa até as formas mais atenuadas, em que são permitidas vendas diretas pelo produtor, eomportando remuneração do intermediário, ou vendas diretas a clientes particulares, com os quais este prefere tratar diretamente ou já tinha relações no passado, sem que haja remuneração por parte do intermediário, ou remunerando-o de modo especial.

Por vezes, o intermediário exige do fabricante a obrigação de 
proteger-Ihe o território, proibindo importações paralelas, vedando a outros intermediários vender nesta zona.

Essas disposições, como se adiantou, correm o risco de incidir nas proibições da legislação antimonopolística.

\section{$\S 2^{\circ}$ - Comissão}

É preciso que se estabeleça, em cláusula contratual, a obrigação, para com o concessionário, de fornecer-lhe os produtos e, para com o agente, de o produtor aceitar e executar os contratos propostos. Ambas as possibilidades também são objeto de nuances, que é preciso determinar no contrato.

Ambas visam a garantir a obrigação fundamental, que é a do pagamento da comissão. O valor desta, a determinação dos negócios que dão direito ao pagamento da comissão - contratos frustrados, falta de mercadoria, falta de pagamento, vendas diretas pelo fabricante, invasão do território de outros concessionários são hipóteses a serem contempladas pelo redator cuidadoso. É preciso também fixar o modo de cálculo da comissão, a moeda de seu pagamento, a época em que este se fará e as condições em que o intermediário fará jus a ele. A boa redação impõe que se esclareça se a comissão incide sobre o preço líquido da mercadoria, ou do preço desta mais fretes, seguros e outras despesas, inclusive fiscais.

Não nos esqueçamos, neste ponto, de mencionar se haverá ou não alguma remuneração de agente em razão de publicidade, feiras, ou outras atividades impostas pelo contratante ou voluntárias, reembolso de despesas bancárias ou financeiras, impostos e taxas que incidirão sobre a comissão.

\section{§3. - Assistência}

Do grupo das obrigações do fabricante, o último é o da informação e da assistência que deve prestar ao intermediário. A assistência, em matéria de propriedade industrial, passa pela orientação técnica e cobertura jurídica. A informação, e o que compreende: condições de venda, material de demonstração, folhetos e amostras; preveja-se a restituição, ou não, desse material, a proibição de divulgar as técnicas de administração e "marketing".

Definidas as grandes linhas do contrato quanto às obrigações específicas das partes, chegamos aos problemas relativos à sua cessação e disposições finais.

\section{e. Cessação do contrato e disposições finais}

O contrato de intermediação, como qualquer outro, pode ter uma duração determinada. Inicia-se, em geral ao ser assinado; não ocorrendo isso, convém determinar o dia em que entrará em vigor.

\section{$\S 11^{\circ}$ - Causas de rescisão e prazo}

Na hipótese de ser por prazo determinado, termina ao chegar o dia ajustado. Pode-se prever, nesta hipótese, a renovação tácita. Pode-se prever, também, a duração determinada sem renovação tácita, com a exigência de novas negociações para esse fim. É preciso, 
porém, indagar-se se o direito local não prevê a continuação do contrato por prazo indeterminado, quando se vence, e se não há denúncia formal.

O contrato com prazo indeterminado, sendo o mais suscetível de gerar conflitos, deve merecer especial atenção quanto às condições de rescisão. Há quem o célebre com período de experiência prévia, durante o qual as partes expressamente convencionam poder rescindi-lo, sem que haja indenização, de lado a lado.

A rescisão, como é óbvio, pode, também, ocorrer nos contratos por prazo determinado. É preciso prever as conseqüências da rescisão, quanto ao destino do estoque, ou depósito de produtos em poder do intermediário, dos pedidos em curso, da proibição de continuar a utilizar a marca do produtor, da restituição do material publicitário e mostruários, e da continuidade dos serviços de assistência e garantia ao consumidor. Não se olvidem as comissões pendentes, o direito de indenização por criação da clientela.

Será preciso, também, estudar à luz do direito local a indenização pela rescisão e, quando esta for omissa, estabelecê-la contratualmente. Por último, são de praxe, como em outros contratos, as chamadas disposições finais.

\section{$\S 2$. - Disposições finais}

Lei aplicável, foro competente e arbitragem, a que já nos referimos na primeira parte deste trabalho, devem ser aqui colocadas.

Na hipótese de contrato traduzido para uma língua estrangeira, estabelecer qual o texto autêntico, e qual a versão.

É preciso, ainda, ressaltar a validade do resto do contrato, se ocorrer nulidade de alguma cláusula. Costuma-se, ainda, prever o exercício do direito de retenção, quer pelo agente, da mercadoria em seu poder, quer das comissões devidas, pelo produtor.

Também se usa incluir cláusulas relativas à proibição de ceder o contrato, ao fato de que todas as modificações ao mesmo serão feitas por escrito, e que aquele contrato revoga todas as correspondências, negócios, tratativas e contratos anteriores.

Evidentemente, nos limites propostos, eram as observações que cabia fazer, sendo certo que com elas não se esgotou a matéria.

\section{Bibliografia}

1. BAPTISTA, Luis Olavo. Contratos internacionais. Revista Forense, Rio de Janeiro, 270 (2): 87-90, abr./jun., 1980.

2. BATIFFOL, Henri. Les conflits de lois em matiére de contrats; étude de droit international privé. Paris, Librairie du Recuel Sirey, 1938.

3. BORTOLOTTI, Fábio. Guida alla stipulazione di contratti con agentie concessionariall'estero. Milão, II Sole 24 Ore, s.d.

4. FERREIRA, Waldemar. A incompatibilidade de cargo, ofício ou função pública com o exercício do comércio. In: _. Tratado de direito comercial. São Paulo, Saraiva, 1960 v. 2, cap. 3, p. 209-13, art. 274, §43. p. 209-13. 
5. GRAULICH, Paul. Régles de conflit e trégles d'application immediate; melanges Dabin II. Paris, Dalloz, 1961.

6. LEÃES, Luiz Gastão Paes de Barros. Indenização em contrato de representante comercial autônomo. In: Direito comercial; textos e pretextos. São Paulo, Jcsé Bushatsky, 1976. Cap. 4, p. 7998.

7. LOUSSOUARN, Yvon § BOUREL, Pierre. Droit international privé. Paris, Dalloz, 1978.

8. LOUSSOUARN, Yvon § BREDIN, Jean-Denis. Droit du commerce international. Paris, Sirey, 1969.

9. MARTINS, Fran. Representantes comerciais, concessionárias e correspondentes. In: Curso de direito comercial; empresa comercial, empresários individuais, sociedades comerciais, fundo de comércio. 5. ed., Rio de Janeiro, Forense, 1976. Cap. 11, art. 107, p. 176-79.

10. MELLO, Oswaldo Aranha Bandeira de. Natureza jurídica dos corretores oficiais; os corretores oficiais não são funcionários públicos. São comerciantes. São Paulo, Prefeitura do Município de São Paulo, 1943.

11. MENDONÇA, José Xavier Carvalho de. Do contrato de comissão mercantil; generalidades. In: Tratado de direito comercial brasileiro. 5. ed. posta em dia por Aquiles Beviláqua e Roberto CarvaIho de Mendonça. Rio de Janeiro, Forense, 1955. V. 6, part. 2, cap. 4, p. $282-85$.

In: v. 6, part. 1, cap. 2, seção 5, p. 198-207. DA REPRESENTAÇÃO do negócio jurídico

12. MERCADAL, barthelemy \& JANIN, Philippe. Les contrats de cooperation enterentreprises. Paris, Lefebre, 1974.

13. MINGUZZI, Rubens B. Mediadores comerciais; corretores de imóveis de seguros e de oficiais de valores, representantes comerciais autônomos, viajantes ou pracistas, Previdência Social. São Paulo, Resenha Tributária, 1972.

14. PEREIRA, Pedro Barbosa. Agentes auxiliares do comércio; dependentes e independentes. In: Curso de direito comercial. São Paulo, Ed. Revista dos Tribunais, 1975. v. 1, cap. 10, part. 2, p. 10719.

15. REQUIÃO, Rubens. Representantes comerciais. In: Curso de direito comercial. 8. ed. São Paulo, Saraiva, 1977. v. 1, p. 141-52.

16. 1977. Do representante comercial. 2. ed. Rio de Janeiro, Forense,

17. SERPA LOPES, Miguel Maria de. Comentário teórico-prático da LICC. Rio de Janeiro, Freitas Bastos, 1959. v. $2 \S 240$.

18. TENÓRIO, Oscar. Direito internacional privado. 11. ed. Rio de Janeiro, Freitas Bastos, 1976.

19. TEYSSIE, Bernard. Les groupes de contrats. Paris, LGDJ, 1975, p. $16,205,210$ ess., 221, 562 .

20. VALLADÃO, Haroldo. Direito internacional privado. Rio de Janeiro, Freitas Bastos, 1970.v. 2. 